\title{
PERENCANAAN STRUKTUR KOMPOSIT BAJA-BETON DENGAN METODE LRFD (LOAD AND RESISTANCE FACTOR DESIGN) RUANG KELAS LANTAI III SMK PARIWISATA LABUAN BAJO - FLORES - NTT
}

\author{
I Wayan Giatmajaya ${ }^{1}$, I Gede Oka Darmayasa ${ }^{2}$, Ni Ketut Sri Astati Sukawati ${ }^{3}$ \\ 1Jurusan Teknik Sipil, Fakultas Teknik, Universitas Mahasaraswati Denpasar \\ 2Jurusan Teknik Sipil, Fakultas Teknik, Universitas Mahasaraswati Denpasar \\ 3 Jurusan Teknik Sipil, Fakultas Teknik, Universitas Mahasaraswati Denpasar \\ Jalan Kamboja No. 11 A Denpasar - Bali \\ Email : wayangiatmajaya1@gmail.com
}

\begin{abstract}
Abstrak - Perencanaan struktur komposit baja-beton menggunakan metode LRFD (Load and Resistance Factor Design) adalah metode yang memperhitungkan secara jelas keadaan batas, aneka ragam faktor beban, dan faktor resistensi, dimana dalam hal ini faktor resistensi diperlukan untuk menjaga kemungkinan kurangnya kekuatan struktur, sedangkan faktor beban digunakan untuk mengantisipasi kemungkinan adanya kelebihan beban yang dirumuskan. Perencanaan ini menggunakan struktur komposit yang difokuskan pada balok baja profil, pelat dek baja, dan kolom komposit. Beban mati dan beban hidup dihitung berdasarkan peraturan pembebanan Indonesia untuk gedung 1983, sedangkan beban gempa dihitung berdasarkan dengan tata cara perencanaan ketahanan gempa untuk struktur bangunan gedung dan non gedung yang tertuang dalam SNI 17622012. Struktur komposit baja - beton sendiri dihitung berdasarkan spesfikasi untuk perencanaan bangunan struktur baja dengan metode LRFD yang tertuang dalam SNI 03-1729-2002. Analisis struktur berupa besarnya gaya yang bekerja pada bangunan dilakukan menggunakan aplikasi SAP2000 sedangkan analisis kelayakan penggunaan dimensi struktur komposit berdasarkan SNI yang digunakan dilakukan secara manual. Dari hasil perencanaan diperoleh besarnya dimensi penampang balok dan kolom untuk masing-masing pelat lantai 1, 2, dan 3 adalah B1 250/250, B2 250/175, B3 300/150, dan K1 350/350. Penggunaan dek baja pada pelat lantai 1, 2, dan 3 menggunakan shear connector (stud) berdiameter $19 \mathrm{~mm}$ dengan masing-masing penghubung geser yang digunakan berjumlah 40 buah, 20 buah, dan 25 buah. Sambungan yang digunakan pada balok induk dan anak masing-masing pada lantai 1, 2, dan 3 menggunakan baut berdiameter $19 \mathrm{~mm}$ dengan jumlah baut masing-masing adalah 4 baut, 2 baut, dan 4 baut, sedangkan sambungan pada kolom dan balok menggunakan baut berdiameter $20 \mathrm{~mm}$ dengan jumlah bautnya 8 buah.
\end{abstract}

Kata kunci : Komposit, $L R F D$, balok baja profil, pelat dek baja, Shear Connector

\begin{abstract}
Planning a steel-concrete composite structure using the LRFD (Load and Resistance Factor Design) method is a method that clearly takes into account the boundary conditions, various load factors, and resistance factors, where in this case the resistance factor is needed to maintain the possible lack of structural strength, while the factor load is used to anticipate the possibility of an overload that is formulated. This planning uses a composite structure that is focused on profile steel beams, steel deck plates, and composite columns. Dead and live loads are calculated based on the Indonesian loading regulations for 1983 buildings, while earthquake loads are calculated based on the earthquake resistance planning procedure for building and non-building structures as stipulated in SNI 1762-2012. The steel-concrete composite structure itself is calculated based on the specifications for the design of steel structure buildings using the LRFD method as stated in SNI 03-1729-2002. The structural analysis in the form of the magnitude of the force acting on the building was carried out using the SAP2000 application while the analysis of the feasibility of using the dimensions of the composite structure based on the SNI used was done manually. From the planning results, the dimensions of beam and column cross-sections for each floor plate 1, 2 and 3 are B1 250/250, B2 250/175, B3 300/150, and K1 350/350. The use of steel decks on floor plates 1, 2, and 3 uses shear connectors (studs) with a diameter of $19 \mathrm{~mm}$ with 40,20, and 25 shear connectors, respectively. The joints used in the main and child beams on floors 1, 2, and 3 respectively use $19 \mathrm{~mm}$ diameter bolts with 4 bolts, 2 bolts, and 4 bolts respectively, while the connections to columns and beams use diameter bolts $20 \mathrm{~mm}$ with the number of bolts 8 pieces.
\end{abstract}

Keyword : Composite; LRFD; profile steel beam; steel deck plate; Shear Connector 


\section{PENDAHULUAN}

Struktur komposit merupakan struktur yang terdiri dari dua material atau lebih dengan sifat bahan yang berbeda dan membentuk satu kesatuan sehingga menghasilkan sifat gabungan yang lebih baik yaitu sama-sama memikul beban. Komposit baja dengan beton didasarkan pada pemikiran bahwa beton mempunyai perilaku yang menguntungkan ketika menerima beban tekan dan perilaku yang kurang menguntungkan ketika menerima beban tarik. Sedangkan baja mempunyai kemampuan bahan yang sama baik untuk beban tarik dan tekan tetapi harus diwaspadai terhadap bahaya tekuk ketika menerima beban tekan. Penggunaan struktur komposit pada bangunan memberikan beberapa keuntungan yaitu dapat mereduksi berat profil baja yang dipakai, mengurangi tinggi profil baja yang digunakan, meningkatkan kekakuan lantai, serta dapat menambah panjang bentang layan.. LRFD (Load and Resistance Factor Design) adalah metode yang memperhitungkan secara jelas keadaan batas, aneka ragam faktor beban dan faktor resistensi, dimana dalam hal ini faktor resistensi diperlukan untuk menjaga kemungkinan kurangnya kekuatan struktur sedangkan faktor beban digunakan untuk mengantisipasi kemungkinan adanya kelebihan beban yang dirumuskan $\phi \mathrm{Rn} \geq$ syiQi. Ruang kelas SMK PARIWISATA Labuan Bajo - Flores - NTT sebelumnya menggunakan struktur beton bertulang, pada perencanaan ini struktur bangunan ruang kelas menggunakan struktur komposit pada balok-plat dan kolom. Ruang kelas ini direncanakan terdiri dari dari 3 (tiga) lantai dengan luas sebesar $16 \quad \mathrm{~m} \quad \mathrm{x} \quad 6 \quad \mathrm{~m}$. Perencanaan ruangan kelas ini menggunakan metode LRFD (Load and Resistance Factor Design).

\section{TINJAUAN PUSTAKA}

\section{Pembebanan}

Beban Mati, adalah berat dari semua bagian suatu gedung /bangunan yang bersifat tetap selama masa layan struktur, termasuk unsurunsur tambahan, finishing, mesin-mesin serta peralatan tetap yang merupakan bagian tak terpisahkan dari gedung/bangunan tersebut.
Termasuk dalam beban ini adalah berat struktur, pipa-pipa, saluran listrik, AC, lampulampu, penutup lantai, dan plafon, Beban Hidup, adalah beban gravitasi yang bekerja pada struktur dalam masa layannya dan timbul akibat penggunaan suatu gedung. Termasuk beban ini adalah berat manusia, perabotan yang dapat dipindah-pindah, kendaraan dan barang-barang lain. Karena besar dan lokasi beban yang senantiasa berubah-ubah, maka penentuan beban hidup secara pasti adalah merupakan suatu hal yang cukup sulit, Beban Gempa adalah semua beban statik ekuivalen yang bekerja ada struktur akibat adanya ergerakan tanah oleh gempa bumi, baik pergerakan arah vertikal maupun horizontal. Namun pada umumnya percepatan tanah arah horizontal lebih besar daripada arah vertikalnya, sehingga pengaruh gempa horizontal jauh lebih menentukan daripada gempa vertikal. Besarnya gaya geser dasar (static ekuivalen) ditentukan berdasarkan persamaan $\mathrm{V}=\frac{[x I}{R} \times \mathrm{W}_{\mathrm{t}}$, dengan $\mathrm{C}$ adalah factor respon gempa yang ditentukan berdasarkan lokasi bangunan dan jenis tanhnya, I adalah factor keutamaan gedung, $R$ adalah factor reduksi gempa yang tergantung pada jenis struktur yang bersangkutan, sedangkan $\mathrm{W}_{\mathrm{t}}$ adalah berat total bangunan termasuk beban hidup yang bersesuaian. Berdasarkan peraturan SNI - 1762 - 2012 tentang "Tata Cara Perencanaan Ketahanan Gempa Untuk Struktur Bangunan Gedung dan Non Gedung".

\section{Program Sap2000}

Program SAP2000 yang akan digunakan adalah untuk mencari besarnya momen $(\mathrm{Mu})$ akibat beban yang bekerja pada bangunan dan gaya geser yang terjadi $(\mathrm{Vu})$ akibat beban gempa yang menimpa bangunan.

\section{Tegangan Elastisitas Kolom Komposit}

Untuk dapat menghitung tegangan-tegangan pada suatu penampang komposit, diperlukan transformasi penampang. Umumnya penampang beton ditransfomasikan menjadi baja, namun mempunyai efek yang sama dengan beton.

Hubungan antara tegangan dan regangan baja dan beton dapat dinyatakan sebagai berikut : 


$$
\varepsilon_{e}=\varepsilon_{g} \text { atau } \frac{f_{c}}{E_{c}}=\frac{f_{s}}{E_{s}}
$$

atau $f_{s}=\frac{E_{m}}{E_{\Sigma}} \quad f_{c}=\mathrm{n} \cdot f_{c}$

Dengan $: E_{c}=$ modulus elastisitas beton

$\mathrm{E}=$ Modulus elastisitas baja $\left(2 \times 10^{6}\right.$

$\mathrm{kg} / \mathrm{cm}^{2}$ )

$$
\mathrm{n}=\frac{E_{\mathrm{m}}}{E_{\mathrm{c}}}=\text { rasio modulus }
$$

Modulus elastisitas beton diberikan dalam SNI-03-1729-2002 Pasal 12.3.2:

$$
E_{c}=0,041 \mathrm{w}^{1,5} \quad \sqrt{f_{c}^{t}}
$$
beton $\left(2400 \mathrm{~kg} / \mathrm{m}^{3}\right)$

Dengan : w adalah berat jenis berumur 28 hari $(\mathrm{MPa})$

$$
f_{e}^{f} \text { adalah kuat tekan beton }
$$

Berat jenis beton normal dapat diambil sebesar $2400 \mathrm{~kg} / \mathrm{m}^{3}$

besarnya tegangan lentur pada bagian atas dan bawah profil baja, dengan menggunaka persamaan :

$$
\begin{aligned}
& f_{s \mathrm{t}}=\frac{M_{0} y_{\mathrm{E}}}{u_{\text {LEr }}} \\
& f_{s b}=\frac{M_{\circ} y_{b}}{I_{\text {Er }}}
\end{aligned}
$$

Dengan : $\mathrm{M}$ adalah momen lentur yang harus dipikul

$I_{\text {tr }}$ adalah momen inersia terhadap sumbu netral

yt adalah jarak dari sumbu netral ke serat atas profil baja

yb adalah jarak dari sumbu netral ke serat bawah profil baja

Tegangan yang terjadi pada serat atas beton dihitung berdasarkan persamaan

$$
f_{e}=\frac{M \cdot \tilde{Y}}{n \cdot I_{\text {LF }}}
$$

\section{Kuat Lentur Nominal}

Kuat lentur nominal dari suatu komponen struktur komposit (untuk momen positif), menurut SNI 03-1729-2002 Pasal 12.4.2.1 ditentukan sebagai berikut :

$$
\begin{aligned}
& \text { a. Untuk } \frac{h^{2}}{t_{\mathrm{w}}} \leq \frac{1680}{\sqrt{f_{Y f}}} \\
& \text { Dengan }: \mathrm{h}=\text { Tinggi profil baja }(\mathrm{m}) \\
& t_{w}=\text { Tebal plat }(\mathrm{m}) \\
& F y=\text { Kuat leleh baja (mpa) }
\end{aligned}
$$

$M_{\mathrm{n}}$ kuat momen nominal yang dihitung berdasarkan distribusi tegangan pada penampang komposit $\Phi_{\mathrm{b}}=0,85$

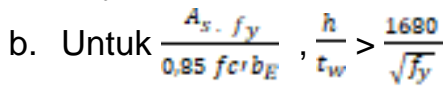

Dengan : $A_{s}=$ Luas penampang profil baja $\left(\mathrm{mm}^{2}\right)$

$\mathrm{Mn}$ kuat momen nominal yang dihitung berdasarkan superposisi tegangan-tegangan elastis yang memperhitungkan pengaruh tumpuan sementara (perancah)

$\Phi \mathrm{b}=0,90$

Kuat lentur nominal yang dihitung berdasarkan distribusi tegangan, dapat dikategorikan menjadi dua kasus sebagai berikut :

1. Sumbu netral jatuh pada pelat beton Dengan mengacu pada gambar 2.4, maka besar gaya tekan $\mathrm{C}$ adalah :

$$
C=0,85 \cdot f_{c}^{\prime} \cdot a \cdot b_{E}
$$

Gaya tarik T pada profil baja adalah sebesar :

$$
T=A_{s} \cdot f_{y}
$$

Dari keseimbangan gaya $\mathrm{C}=\mathrm{T}$, maka diperoleh :

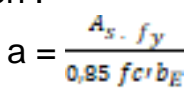

Kuat lentur nominal dapat dihitung dari Gambar 2.3.b :

$$
\begin{aligned}
M n & =\mathrm{C} \cdot d_{1} \\
\text { atau } \quad M n & =\mathrm{T} \cdot d_{1}=\mathrm{A}_{\mathrm{s}} \cdot \mathrm{f}_{\mathrm{y}}\left(\frac{\mathrm{d}}{2}+\mathrm{t}_{\mathrm{s}}-\frac{\mathrm{a}}{2}\right)
\end{aligned}
$$

\section{Lendutan}

Komponen struktur komposit memiliki momen inersia yang lebih besar daripada komponen struktur non komposit, akibatnya lendutan pada komponen struktur komposit akan lebih kecil. Momen inersia dari komponen struktur komposit hanya dapat tercapai setelah beton mengeras, sehingga lendutan yang diakibatkan oleh beban-beban yang yang bekerja sebelum beton mengeras. Dihitung berdasarkan momen inersia dari profil baja 
saja. (Setiawan A, 2008). Pada daerah momen positif, beton akan mengalami tekan secara berkesinambungan yang akan mengakibatkan beton mengalami gejala rangkak (creep). Rangkak adalah salah satu bentuk deformasi struktur yang terjadi akibat beban tekan yang bekerja secara terus menerus. Setelah deformasi awal tercapai, deformasi tambahan yang diakibatkan rangkak akan terjadi secara perlahan dan dalam jangka waktu yang cukup lama. Lendutan jangka panjang yang terjadi pada komponen struktur komposit dapat diperkirakan dengan cara mengurangi luas pelat beton sehingga momen inersia akan mengecil. Luasan pelat beton biasanya direduksi dengan cara membagi lebar pelat dengan angka $2 n$ atau $3 n$, dengan $n$ adalah rasio modulus. (Setiawan A, 2008)

\section{Kolom Komposit}

Kolom komposit dibentuk dari profil baja hasil gilas panas yang dibungkus dengan beton. Persyaratan bagi suatu kolom komposit ditentukan daam SNI 03-1729-2002 pasal 12.3.1. Batasan-batasan berikut harus dipenuhi oleh suatu kolom komposit :

a. Luas penampang profil baja minimal sebesar $4 \%$ dari luas total penampang melintang kolom komposit, jika kurang maka komponen struktur tekan ini akan beraksi sebagai kolom beton biasa.

b. Untuk profil baja yang diselubungi beton, persyaratan berikut harus dipenuhi :

1) Tulangan longitudinal dan lateral harus digunakan, jarak antar pengikat lateral tidak boleh lebih besar dari 2/3 dimensi terkecil penampang kolom komposit.

2) Selimut beton harus diberikan minimal setebal $40 \mathrm{~mm}$ dari tepi terluar tulangan longitudinal dan transversal

3) Tulangan longitudinal harus dibuat menerus pada lantai tingkat kecuali tulangan longitudinal yang hanya berfungsi sebagai kekangan beton c. Kuat tekan beton fc' berkisar antara 21 hingga $55 \mathrm{MPa}$ untuk beton normal dan minimal $28 \mathrm{MPa}$ untuk beton ringan.

d. Tegangan leleh profil baja tulangan longitudinal tidak boleh melebihi $380 \mathrm{MPa}$.

\section{Alat Penyambung Geser (Shear Connector)}

Gaya geser yang terjadi antar pelat beton dan profil baja harus dipikul oleh sejumlah penghubung geser, sehingga tidak terjadi slip pada saat masa layan. Besarnya gaya geser horizontal yang harus dipikul oleh penghubung geser diatur dalam SNI 03-1729-2002 Pasal 12.6.2. Pasal ini menyatakan bahwa untuk aksi komposit dimana beton mengalami gaya tekan akibat lentur, gaya geser horizontal total yang bekerja pada daerah yang dibatasi oleh titiktitik momen positif maksimum dan momen nol yang berdekatan, harus diambil sebagai nilai terkecil dari : $A_{\mathrm{s}} \cdot f_{\mathrm{y}}, 0,85 . f_{\mathrm{c}}{ }^{\prime} \cdot A_{\mathrm{c}}$ atau $\sum \mathrm{Q}_{\mathrm{n}}$. Selanjutnya notasikan gaya geser horizontal ini dengan $V_{\mathrm{h}}$.

\section{Dek Baja Gelombang}

Persyaratan dek baja gelombang dan penghubung gesernya untuk digunakan dalam komponen struktur komposit diatur dalam SNI 03-1729-2002 Pasal 12.4.5.1. Dalam pasal ini dipersyaratkan :

1. Tinggi maksimum dek baja, $\mathrm{h}_{\mathrm{r}} \leq$ $75 \mathrm{~mm}$

2. Lebar rata-rata minimum dari gelombang dek, $\mathrm{W}_{\mathrm{r}}>50 \mathrm{~mm}$, lebar ini tidak boleh lebih besar dari lebar bersih minimum pada tepi atas dek baja

3. Tebal pelat minimum diukur dari tepi atas dek baja $=50 \mathrm{~mm}$

4. Diameter maksimum stud yang dipakai $=20 \mathrm{~mm}$, dan dilas langsung pada flens balok baja

5. Tinggi maksimum stud diukur dari sisi dek baja paling atas $=40 \mathrm{~mm}$

\section{Sambungan Baut}

$R u \leq \phi \cdot R n$. Dengan $R n$ adalah tahanan nominal baut sedangkan $\phi$ adalah faktor reduksi yang diambil sebesar 0.75 . besarnya $R n$ berbeda-beda untuk masing- masing tipe sambungan. (Setiawan A, 2008). Tahanan geser satu buat baut yang memikul gaya geser 
memenuhi persamaan: $R n=m \cdot r_{1} \cdot f_{u}^{b} A_{b}$. Baut yang memikul gaya tarik tahanan nominalnya dihitung menurut: $R n=0.75 f_{u}^{b} A_{b}$. Tahanan tumpu nominal tergantung kondisi yang terlemah dari baut atau komponen plat yang disambung. Besarnya ditentukan sebagai berikut: $R n=2.4 d_{b} t_{p} f_{u}$.

\section{METODE PERENCANAAN}

Lokasi Perencanaan

Lokasi Bangunan terletak di Jl. Raymundus Rambu No. 1 Batu Cermin, Kec. Komodo, Kabupaten Manggarai Barat, Provinsi Nusa Tenggara Timur (NTT)

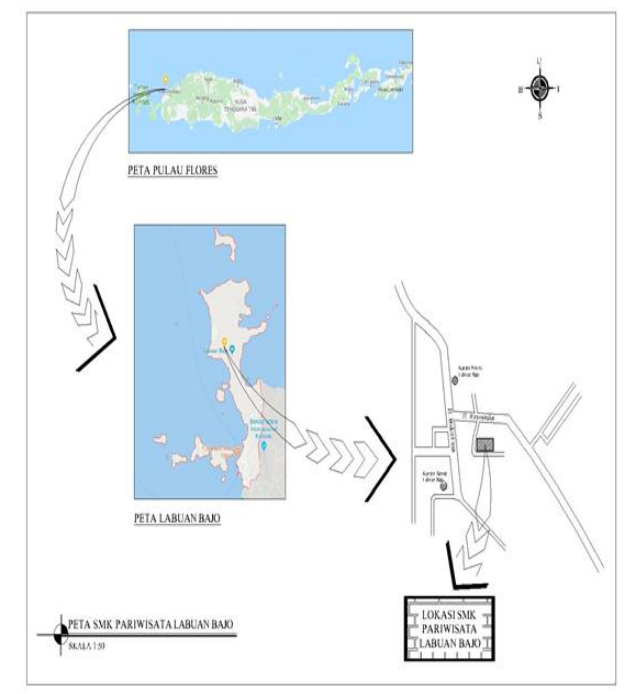

Gambar 1. Lokasi Perencanaan

\section{Perencanaan Pelat Lantai}

Perencanaan pelat lantai menggunakan dek baja gelombang dengan rincian sebagai berikut berdasarkan SNI 03-1729-2002 Pasal 12.4.5.1 :

1. Digunakan $h_{r}=50 \mathrm{~mm}$

2. Digunakan $\mathrm{w}_{\mathrm{r}}=200 \mathrm{~mm}$

3. Tebal pelat lantai $=120 \mathrm{~mm}$

4. Diameter stud $=19 \mathrm{~mm}$

5. Tinggi stud $=70 \mathrm{~mm}$

6. Mutu beton yang digunakan adalah K250

\section{Perencanaan Portal bangunan}

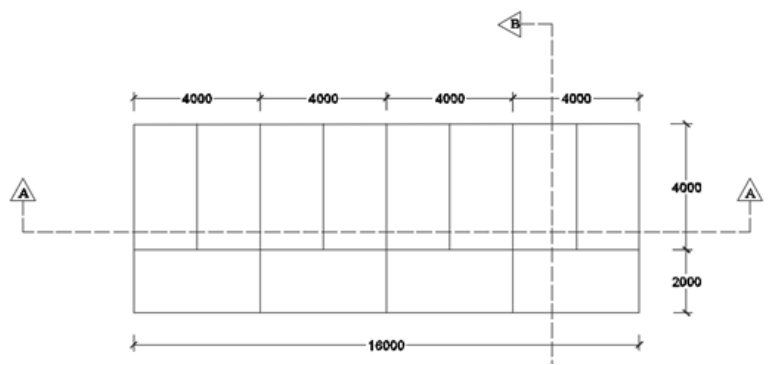

Gambar 2. Denah Bangunan

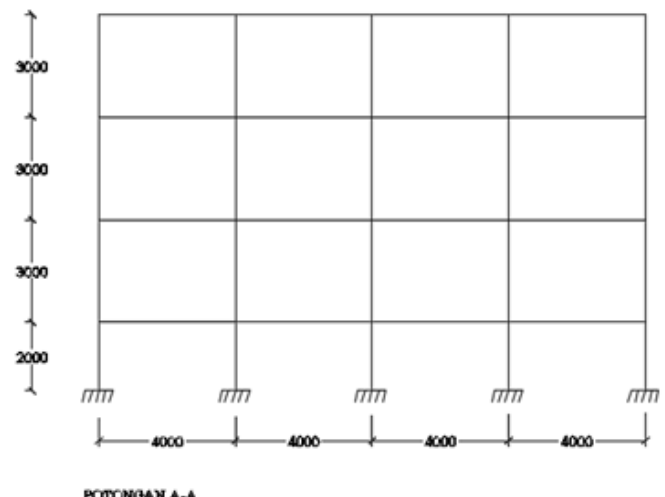

Gambar 3. Potongan A-A

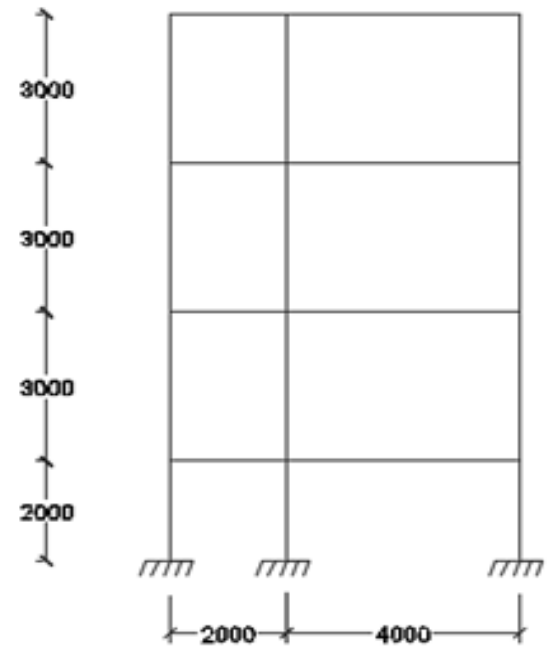

POTONGAN B-B

Gambar 4. Potongan B-B 


\section{Perencanaan Balok Komposit}

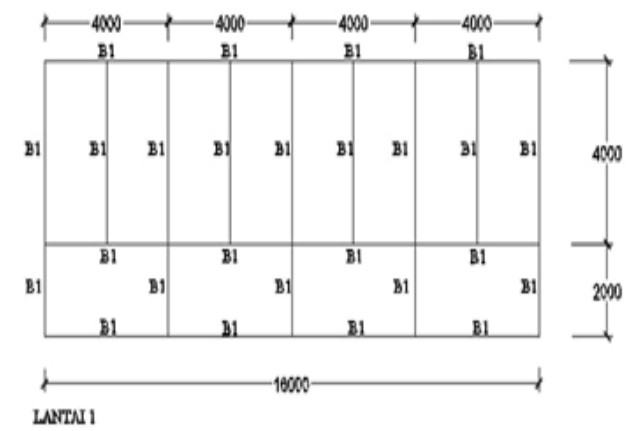

Gambar 4. Denah Balok

\section{Perencanaan Kolom Komposit}

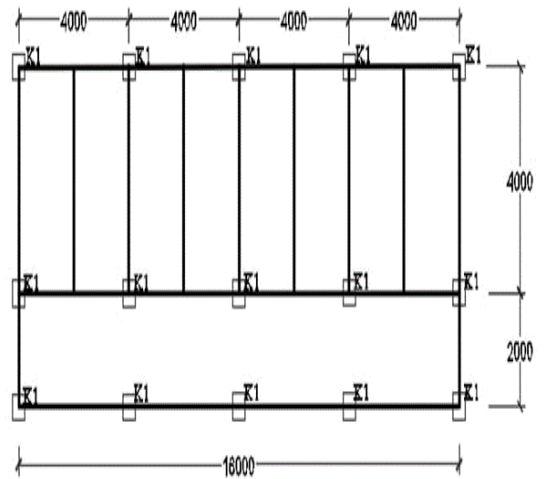

Gambar 5. Denah Kolom

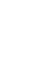

\section{Kerangka Pikir dan Bagan Alir}

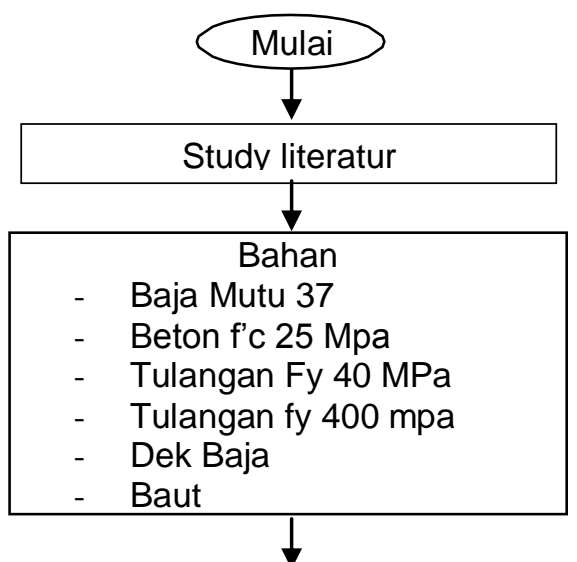

Kajian Konstruksi Komposit

- Beban

- Balok

- Plat

- Kolom

- Penyambung Geser

- Sambunaan

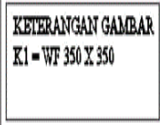

KBIBRANGANGAMAR

-

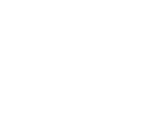




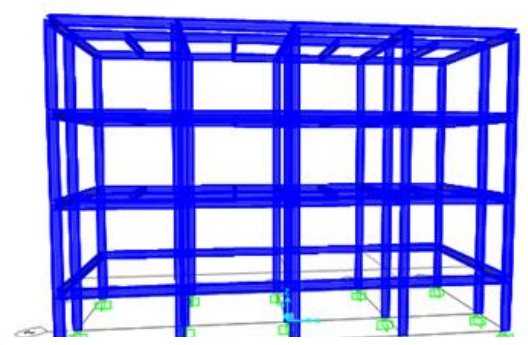

Gambar 6. Portal Arah Depan

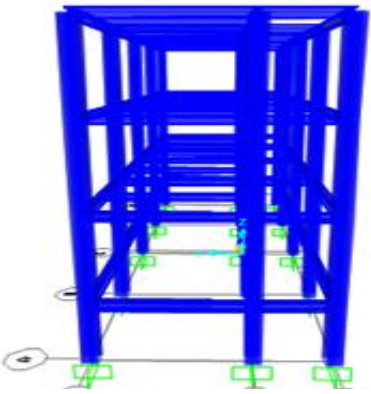

Gambar 7. Portal Arah Samping

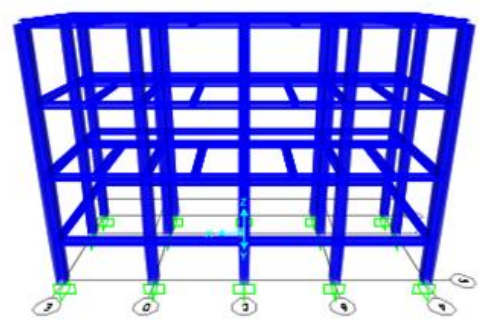

Gambar 8. Portal Arah Belakang

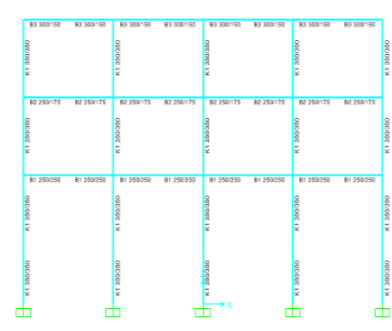

Gambar 9. Run Analyziz

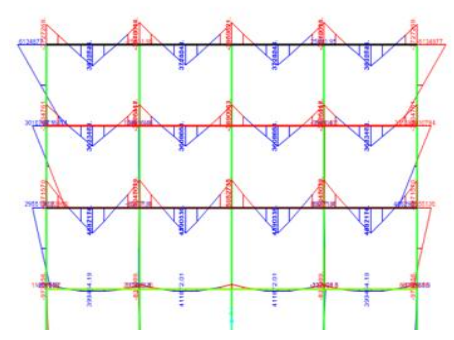

Gambar 10. Bidang Momen

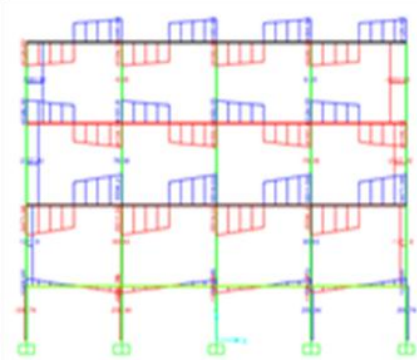

Gambar 11. Gaya Lintang

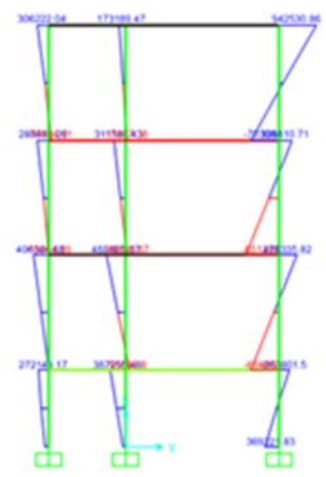

Gambar 12. Gaya Geser 


\section{Balok-Pelat Lantai 1}

\section{WF 250.250}

$\mathrm{Mu}=13.975 .757,7 \mathrm{Nmm}=139.757,557 \mathrm{~kg} \mathrm{~cm}$ $\mathrm{Vu}=20.286,566 \mathrm{~N}$

Kriteria Penampang OK $(21,56 \mathrm{~mm} \leq 108 \mathrm{~mm})$ Momen Inersia $38.095,45 \mathrm{~cm}^{4}$

$\mathrm{Fsa}=22,01 \mathrm{~kg} / \mathrm{cm}^{2}$

$\mathrm{Fsb}=69,70 \mathrm{~kg} / \mathrm{cm}^{2}$

$\mathrm{Fc}=8,25 \mathrm{~kg} / \mathrm{cm}^{2}$

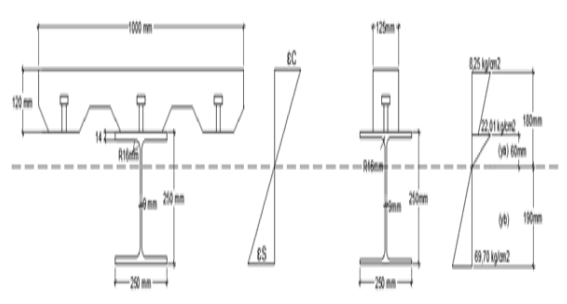

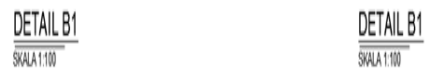

Kuat lentur nominal $=362.887 .582,8 \mathrm{Nmm}>\mathrm{Mu}$ )

Kuat geser $=291.600 \mathrm{~N}>\mathrm{V}_{\mathrm{u}}(20.285,566 \mathrm{~N})$

Penghubung geser $\mathrm{Qn}=110.034,44 \mathrm{~N}$, Asc $\mathrm{x}$ fu

$=113.400 \mathrm{~N}>\mathrm{Qn}$

Jumlah stud $(\mathrm{N})=40$ buah bentang 4 meter

Kontrol lendutan $\mathrm{OK}=1,18 \mathrm{~mm} \leq 16,67 \mathrm{~mm}$

Balok-Pelat Lantai 2

WF 250.175

$\mathrm{Mu}=18.273 .265,7 \mathrm{Nmm}=182.732,657 \mathrm{~kg} \mathrm{~cm}$

$\mathrm{Vu}=14.569,282 \mathrm{~N}$

Kriteria Penampang OK $(28,57 \mathrm{~mm} \leq 108 \mathrm{~mm})$ Momen Inersia $23.817,08 \mathrm{~cm}^{4}$

$\mathrm{Fsa}=17,95 \mathrm{~kg} / \mathrm{cm}^{2}$

$\mathrm{Fsb}=169,25 \mathrm{~kg} / \mathrm{cm}^{2}$

$F \mathrm{c}=13,75 \mathrm{~kg} / \mathrm{cm}^{2}$

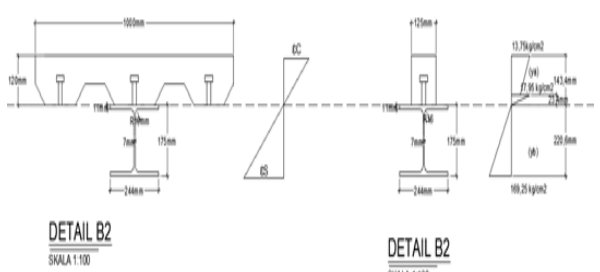

Kuat lentur nominal $=241.064 .617,2$

Kuat geser $=221.356,8 \mathrm{~N}>\mathrm{V}_{\mathrm{u}}(14.569,282 \mathrm{~N})$

Penghubung geser $\mathrm{Qn}=110.034,44 \mathrm{~N}$, Asc $\times$ fu $=113.400 \mathrm{~N}>\mathrm{Qn}$
Jumlah stud $(\mathrm{N})=25$ buah bentang 4 meter Kontrol lendutan $\mathrm{OK}=2,2 \mathrm{~mm} \leq 16,67 \mathrm{~mm}$

Balok-Pelat Atap

WF $\mathbf{3 0 0 . 1 5 0}$

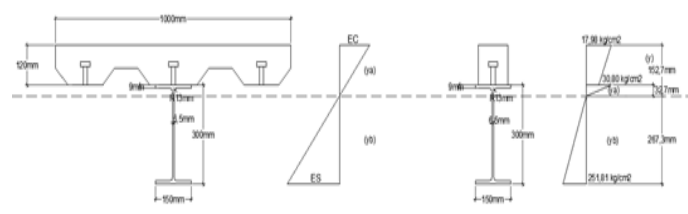

$\frac{\text { DETAIL B3 }}{\frac{\text { SKALAT100 }}{2-10}}$

$\frac{\text { DETALL B3 }}{\text { SEMA }+100}$

$\mathrm{Mu}=26.696 .587,3 \mathrm{Nmm}=266.965,873 \mathrm{~kg} \mathrm{~cm}$

$\mathrm{Vu}=11.264,891 \mathrm{~N}$

Kriteria Penampang OK $(40,61 \mathrm{~mm} \leq 108 \mathrm{~mm})$

Momen Inersia $28.339,29 \mathrm{~cm}^{4}$

$\mathrm{Fsa}=30,80 \mathrm{~kg} / \mathrm{cm}^{2}$

$\mathrm{Fsb}=251,81 \mathrm{~kg} / \mathrm{cm}^{2}$

$\mathrm{Fc}=17,98 \mathrm{~kg} / \mathrm{cm}^{2}$

Kuat lentur nominal $=232.541 .150,4$

$\mathrm{Nmm}>\mathrm{Mu}(26.696 .587,3 \mathrm{Nmm})$

Kuat geser $=252.720 \mathrm{~N}>\mathrm{V}_{\mathrm{u}}(11.264,891 \mathrm{~N})$

Penghubung geser $\mathrm{Qn}=110.034,44 \mathrm{~N}$, Asc $\times$ fu $=113.400 \mathrm{~N}>\mathrm{Qn}$

Jumlah stud $(\mathrm{N})=20$ buah bentang 4 meter Kontrol lendutan $\mathrm{OK}=1,86 \mathrm{~mm} \leq 16,67 \mathrm{~mm}$

Kolom Komposit

WF $\mathbf{3 5 0 . 3 5 0}$

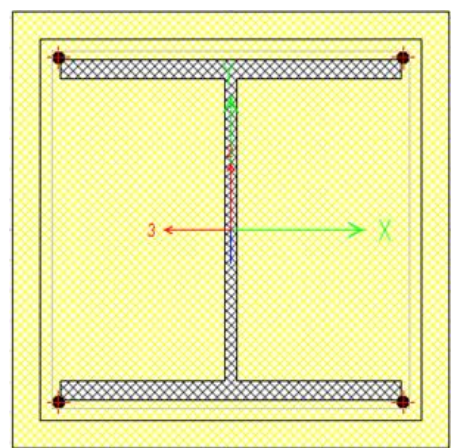

Luas minimum profil baja $A s / A c=8,6 \%>4 \%$ OK

Sengkang $200 \mathrm{~mm}<2 / 3 \times 450 \mathrm{~mm}$ (OK)

Luas tulangan $113,04 \mathrm{~mm}^{2}>0,18 \times 358 \mathrm{~mm}^{2}$ (OK)

Luas sengkang $78,5 \mathrm{~mm}^{2}>36 \mathrm{~mm}^{2}$

Kuat rencana maksimum $\mathrm{OK} 5.163 .750 \mathrm{~N}>\varnothing \mathrm{N}_{\mathrm{nc}}$ $(3.250 .538,8 \mathrm{~N})$

\section{Sambungan}

Balok anak - Induk Lantai 1 


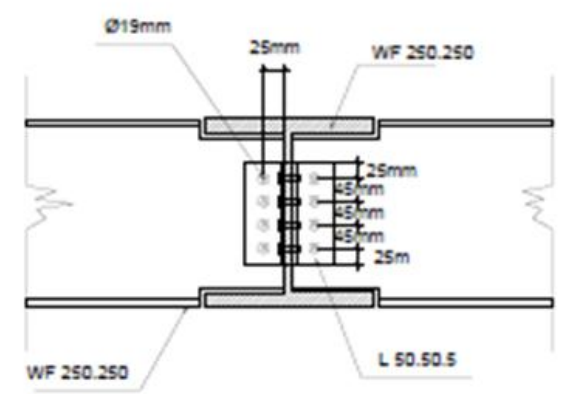

Sambungan baut diameter $19 \mathrm{~mm}$ dan jumlah baut $=4$ baut

Balok anak - Induk Lantai 2

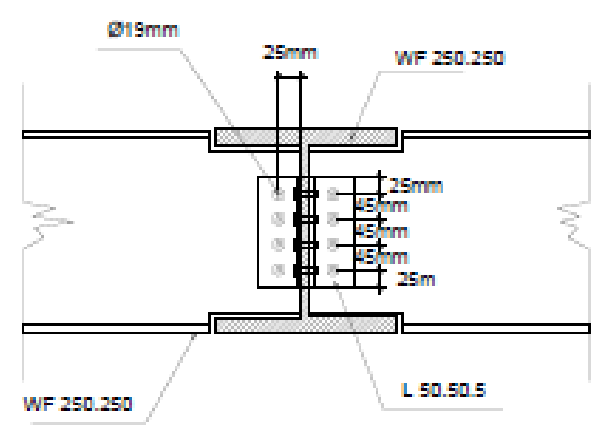

Sambungan baut diameter $19 \mathrm{~mm}$ dan jumlah baut $=2$ baut

Balok anak - Induk Lantai 3

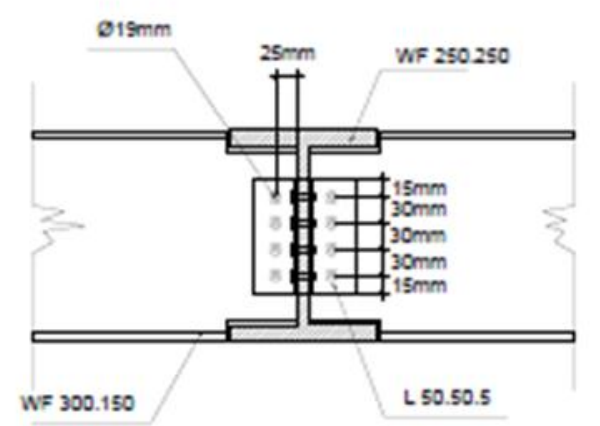

Sambungan baut diameter $19 \mathrm{~mm}$ dan jumlah baut $=4$ baut

Balok Induk - Kolom lantai 1
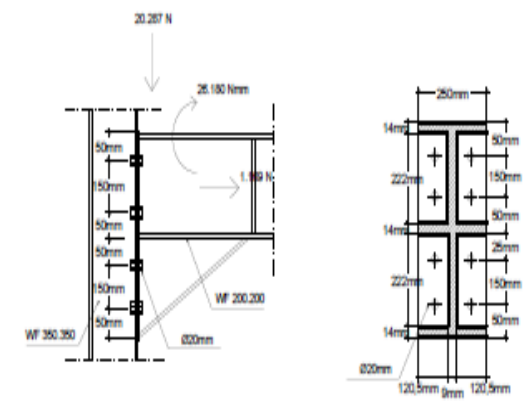

Sambungan diameter $20 \mathrm{~mm}$ dan jumlah baut 8 buah

Balok Induk - Kolom lantai 2

$1450 \mathrm{~N}$
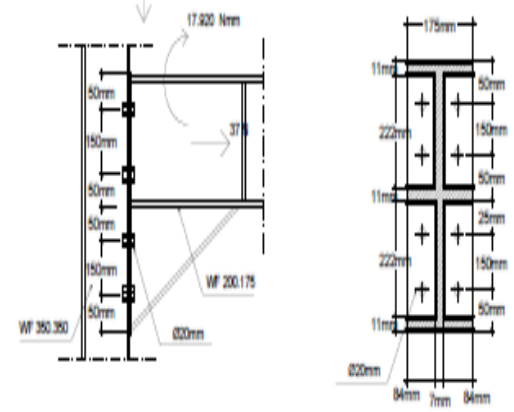

Sambungan diameter $20 \mathrm{~mm}$ dan jumlah baut 8 buah

\section{Balok Induk - Kolom Lantai 3}
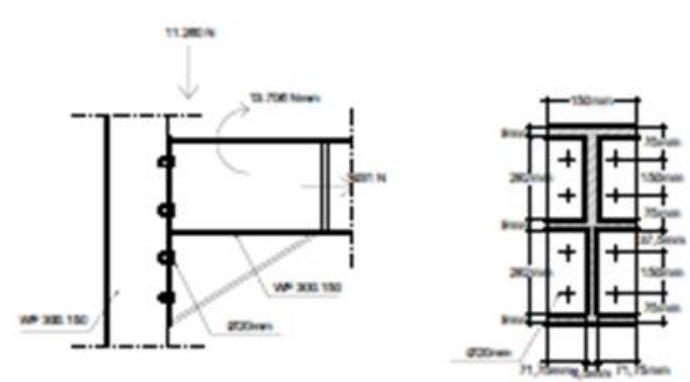

Sambungan diameter $20 \mathrm{~mm}$ dan jumlah baut 8 buah

\section{SIMPULAN DAN SARAN}

Berdasarkan hasil perencanaan yang telah diuraikan, maka dapat disimpulkan sebagai berikut :

1. Dari hasil perencanaan menggunakan aplikasi SAP2000 didapatkan hasil kekuatan struktur bangunan yang aman 
dan sesuai dengan peraturan yang berlaku.

2. Balok yang digunakan sesuai ukuran perencanaan yaitu B1 250/250, B2 250/175, B3 300/150 pada bangunan mampu untuk menerima beban yang bekerja dan dikatakan aman

3. Kolom yang digunakan sesuai ukuran perencanaan yaitu K 350/350 pada bangunan mampu untuk menerima beban yang bekerja dan dikatakan aman.

4. Penggunaan dek baja pada pelat dengan ukuran stud yang digunakan diameter 19 $\mathrm{mm}$, masing-masing pada pelat lantai 1 , 2 dan atap berjumlah 40 buah, 20 buah, dan 25 buah.

5. Sambungan baut yang digunakan pada :

a) Balok induk melintang - Balok Anak memanjang lantai 1 (satu) diameter $19 \mathrm{~mm}$ dengan jumlah baut $=4$ baut.

b) Balok induk melintang - Balok Anak memanjang lantai 2 (dua) diameter $19 \mathrm{~mm}$ dengan jumlah baut $=2$ baut.

c) Balok induk melintang - Balok Anak memanjang atap diameter $19 \mathrm{~mm}$ dengan jumlah baut $=4$ baut.

d) Balok induk melintang lantai satu, dua ,dan atap terhadap kolom dengan jumlah baut $=8$ buah dan baut berdiameter 20 .

Beberapa saran yang disampaikan pada perencanaan ini antara lain :

1. Dalam menentukan profil baja, sebaiknya jangan memilih profil baja yang terlalu besar dan jangan yang terlalu kecil agar tidak menyebabkan pemborosan material dan keadaan abnormal pada struktur bangunan.

2. Dalam perencanaan struktur bangunan sebaiknya mengikuti dan memahami standar-standar atau peraturan yang berlaku.
3. Dalam penggunaan aplikasi SAP2000 dibutuhkan pemahaman agar tidak terjadi kesalahan atau human error.

\section{DAFTAR PUSTAKA}

Dinas, PU. 2017. Desain Spektra Indonesia

http://puskim.pu.go.id/aplikasi/desain_spektra_in donesia_2011/ (25 Juli 2019)

Gunawan, R. 1987. Tabel Profil Konstruksi Baja. Yogyakarta : Penerbit Kanisius

Khatuiistiani, U. 2003. Perencanaan Balok Komposit Menggunakan Metode LRFD. Surabaya : Universitas Wijaya Kusuma

Khafis, M. 2009. Perencanaan Struktur Baja Pada Bangunan Tujuh Lantai Sebagai Hotel. Solo : Universitas Sebelas Maret Surakarta

Mulyono, T. 2003. Teknologi Beton. Jakarta: Penerbit Andi

Muhamad, R.2010. Sambungan baut baja

http://eprints.polsriac.id/1559/6/BAB\%2BABIII2B 4.pdf (6 agustus 2019)

Pujianto, A. 2014. Struktur Komposit Dengan Metode LRFD (Load and Resistance Factor Design).

PPIUG-1983 Tentang Peraturan Pembebanan Indonesia Untuk Gedung

Setiawan, A. 2008. Perencanaan Struktur Baja Dengan Metode LRFD. Jakarta: Penerbit Erlangga

SNI 03 - 1729 - 2002 Tentang Perencanaan Struktur Baja Dengan Metode LRFD. Jakarta: Badan Standarisasi Nasional Indonesia (BSNI)

SNI 1762 - 2012 Tentang Tata Cara Ketahanan Gempa Untuk Struktur Bangunan Gedung dan Non Gedung. Jakarta : Badan Standarisasi Nasional Indonesia (BSNI)

Sri, Y. 2014. Perhitungan Struktur Komposit Pembangunan Ruang Kelas Baru SMP Negerri 44 Kecamatan Palaran Kota Samarinda. Samarinda : Universitas Mulawarman

Universitas Mahasaraswati Denpasar. 2018. Pedoman Tugas Akhir. Denpasar: Fakultas Teknik UNMAS 